\title{
Correlation between I-Learning Skills, Domicile and Student Learning Achievement in Distance Education
}

\author{
Sri Tatminingsih ${ }^{1}{ }^{\bowtie}$ Hulaifi $^{2}$ \\ Pendidikan Guru Pendidikan Anak Usia Dini, Universitas Terbuka, Indonesia(1) \\ Agribisnis, Universitas Terbuka, Indonesia(2) \\ DOI: $\underline{10.31004 / \text { obsesi.v6i4.1703 }}$
}

\begin{abstract}
This article will describe a part of the results of the research that aims to analyze the relationship between literacy skills, domicile and learning outcomes of the Mataram Universitas Terbuka (UT) students. This research was conducted using a correlational survey method. The data were collected with an instrument in the form of a questionnaire. The population is the 2020 Early Childhood Education Teacher (ECET) Program students as many as 982 students. The sample is an ECET Program new students who are in the odd and even semesters of 2020 as many as 213 students. All samples are respondents. The results show that there is no significant relationship between domicile, and student learning achievement and I-literacy with student learning achievement. This is because student learning achievement are based on their ability to read and master the Basic Materials Book. Recommendations that can be conveyed are to prepare new students to study independently, train how to learn to use print and non-print media, including how to understand the content of the Basic Materials Book.
\end{abstract}

Keywords: i-literacy; domicile; student learning achievement; distance education

\begin{abstract}
Abstrak
Artikel ini akan memaparkan bagian dari hasil penelitian yang bertujuan untuk menganalisis hubungan antara keterampilan literasi, domisili dan hasil belajar Mahasiswa Universitas Terbuka (UT) Mataram. Penelitian ini dilakukan dengan metode survei korelasional. Data dikumpulan dengan instrumen berupa angket. Populasi adalah Mahasiswa Program PGPAUD tahun 2020 sebanyak 982 Mahasiswa. Sampel adalah Mahasiswa baru PGPAUD yang yang berada pada semester ganjil dan genap tahun 2020 sebanyak 213 Mahasiswa. Semua sampel adalah responden. Hasil penelitian menunjukan bahwa tidak ada hubungan yang signifikan antara domisili dengan hasil belajar mahasiswa dan I-literasi dengan hasil belajar Mahasiswa. Hal ini disebabkan karena hasil belajar Mahasiswa didasarkan pada kemampuan mereka untuk membaca dan menguasai Buku Materi Pokok (BMP). Rekomendasi yang dapat disampaikan adalah mempersiapkan Mahasiswa baru untuk belajar secara mandiri, melatih cara belajar menggunakan media cetak dan non cetak termasuk cara memahami isi BMP.
\end{abstract}

Kata kunci: i-literasi; domisili; hasil belajar; pendidikan tinggi jarak jauh

Copyright (c) 2021 Sri Tatminingsih, Hulaifi

$\triangle$ Corresponding author :

Email Address : tatmi@ecampus.ut.ac.id (Jl Cabe Raya- Pamulang-Tangerang Selatan)

Received 31 June 2021, Accepted 10 August 2021, Published 8 February 2022 


\section{INTRODUCTION}

The learning system in higher education has a fairly basic difference with the learning system in schools, especially in high school (SMA). For tertiary institutions, students are required to be able to study independently, starting from determining the courses they want to study per semester, how to study they want to do, to choosing study times and lecture days (A. Pramana, R.Watrianthos and I. Purnama, 2019). While in high school, students tend to learn to follow the schedule that has been determined by the school. Every day you have to go to school and do assignments according to the teacher's directions (Ines Rinera and, Sofia Retnowati, 2020). Therefore, new students in college must adapt to the learning system in college. Some research results show that new students at several universities must adapt to the management system in universities including the learning system (Iflah and Winda Dwi L, 2013), administrative system (Wahyu H., Aryono A., Aji P, 2016) and the exam system (Airin T and Clement EP, 2021). In addition, some of them are forced to change their residence to approach the campus where they study and facilitate access to take care of various things on campus (Bahtiar Afwan, 2017). This is also experienced by new students at distance universities. Even though they don't have to change locations to approach their campus, as new students they still want to manage the various files directly to their campus (Iflah and Winda Dwi L, 2013), (Masani, Happy F., Alfroki M., 2021). Another problem faced by new students is related to the administrative system.

Currently, almost all universities are implementing an online administration and lecture system. This system includes the process of documenting administrative data and the lecture process (Wahyu H., Aryono A., Aji P, 2016), (A. Pramana, R.Watrianthos and I. Purnama, 2019). Therefore, new students must also have skills in using online or internetbased devices. (Febrialismanto, 2021), (Nurdin and Anhusadar , 2021). Therefore, students are required to be able to utilize the various media well in order to achieve the expected competencies. In addition, the learning process in distance education or the open distance learning (ODL) is done in face-to-face and online mode (Nina A. Sokolova, et. al, 2018), (Tatminingsih, 2021). With these skills, students will be able to easily assess lectures and material. In addition to these two things, there are other things that also need to be considered in distance education, namely the place where students live or domicile. Why is this important? One of the things that makes this important variable is whether there is an internet network at the location of this student which can be a big support in ODL

The results of interviews with student service officers at UT, information was obtained that 1) almost $80 \%$ of prospective students have difficulty filling out online registration forms. They prefer to collect files manually. 2) Although at UT an online complaint platform is provided (http://hallo-ut.ut.ac.id/), students prefer to directly submit their problems or questions to the student service officer at the UT office. 3) Early semester students tend to have difficulty following online tutorials, this is evidenced by the number of new students who fail to activate on the online tutorial page. 4) The biggest obstacle experienced by early semester students at UT during exams is not knowing the online exam schedule and the process of taking online exams. The data show that the skills to use the internet (I-literacy) need to be possessed by new students.

Based on initial data, researchers are interested in researching the ability to use the internet (I-literacy skill), domicile and learning achievement of new students at UT Mataram. The aim is to find out whether or not there is a relationship between Iliteracy and learning achievement and domicile and student learning achievement. Especially new students at UT Mataram. The novelty in this study lies in the relationship between the three variables. Previously there had been research related to these three variables, but the research conducted was partial on each variable, including research on learning achievement (Suwena, 2017), (Rinera, I., Retnowati, S., 2020), new student learning systems (A. Pramana, R.Watrianthos and I. Purnama, 
2019), (Brady, 2020); new student abilities and conditions (Iflah and Winda Dwi L, 2013), (Haluti F., Layoo N., 2020), (Clement EP., et al, 2019) and the relationship between high school students' residences and their learning achievement (Indriyani, 2014) (Bahtiar Afwan, 2017).

\section{METHODOLOGY}

This study uses the correlational survey research method with a questionnaire as a data collection tool. Sampling is done by random sampling technique. The population is the 2020 ECET students as many as 982 students. The sample is new ECET students who are in the odd and even semesters of 2020 as many as 213 students. All samples are respondents. The following are students who were sampled in this study.

Table 1 Number of ECET Program Students at UT Mataram in 2020

\begin{tabular}{lccccc}
\hline \multirow{2}{*}{ Study Program } & \multicolumn{2}{c}{2020.1} & \multicolumn{2}{c}{2020.2} & \multirow{2}{*}{ Total } \\
\cline { 2 - 5 } & New & Old & New & Old & \\
\hline ECE Teacher Program & $\mathbf{1 7 4}$ & 365 & $\mathbf{3 9}$ & 404 & 982 \\
\hline
\end{tabular}

Table 1 shows that the number of ECET students who registered was 982 students. They consist of new students (student at first semester) and old students (students' semester two and above). The sample is all new students as many as 213 students. They consist of new students in the odd semester (2020.1) as many as 174 and new students in the even semester (2020.2) as many as 39 students. This sampling uses a census technique, which is a technique that uses all samples as respondents.

The data collection process was carried out by distributing questionnaires through the online google form (G-Form) application. All samples are given a G-Form questionnaire links via email or WhatsApp. There were 208 respondents who responded and filled out the questionnaire. After further sorting, including the completeness of the answers, only 200 answers could be extracted and further processed for analysis. The time of the research is March 2020 - February 2021. The collected data is then analyzed by bivariate analysis to see the relationship between the independent variables, namely I-literacy and domicile on the dependent variable, namely student learning achievement.

Data on student learning outcomes are obtained from the cumulative achievement index in the form of the letters $\mathrm{A}, \mathrm{B}, \mathrm{C}, \mathrm{D}$ and $\mathrm{E}$ with a standard value of 4 . The range of values is $\mathrm{A}=3.51-4.00 ; \mathrm{B}=3.01-3.50 ; \mathrm{C}=2.51-3.00 ; \mathrm{D}=2.01-2.50$; and $\mathrm{E}=2.00$. Data about students' I-literacy skills in this research were obtained from the answers to questions in a questionnaire that included I-literacy indicators. The number of questions is 48 items. Each item has a score of 0.5 . So the highest total score is 24 and the lowest value is 0 . Student domicile data were obtained from student statements in answering questionnaire items that included domicile indicators.Each indicator is scored using a Likert scale with a range of 1-4. The categories are $1=$ strongly disagree, $2=$ disagree, $3=$ agree, $4=$ strongly agree. The number of questionable items is 20. The total highest score is 80 and the lowest score is 20.

Data analysis was performed by statistical tests using the Chi-square formula. The degree of trust used is $95 \%(\alpha=0.05)$. If the P-value is smaller than $\alpha(p 0.05)$, it means that there is a significant (significant) relationship between the two variables studied. If the pvalue is greater than $a(p>0.05)$, it means that there is no significant relationship between the two variables studied. 


\section{RESULT AND DISSCUSSION}

\section{An Overview of Ut Mataram.}

UT Mataram is one of 39 Distance Learning Program Units owned by UT. The Distance Learning Program Unit (UPBJJ) is a UT technical implementation unit in the regions. The functions and duties of UPBJJ-UT are at a place for students to carry out academic administrative and academic activities. For daily activities, UPBJJ-UT has the task of providing distance learning services (www.ut.ac.id). UT Mataram serves students in West Nusa Tenggara Province, which includes eight districts namely Bima, Dompu, West Lombok, Central Lombok, East Lombok, North Lombok, Sumbawa, West Sumbawa and two cities, namely Mataram and Bima. The number of UT Mataram students in 2020 is as much as 3200 spread over every district/city. Of these, there are students majoring in basic education as much as 2889. They consist of elementary teacher Education (PGSD) and ECET (PGPAUD) students.

\section{Age of Respondent}

Data about the age of the respondents were presented to find out whether students at UT Mataram belong to the category of Indonesian residents who are actively using the internet. The data can be seen in Figure 1 in the form of a pie chart.

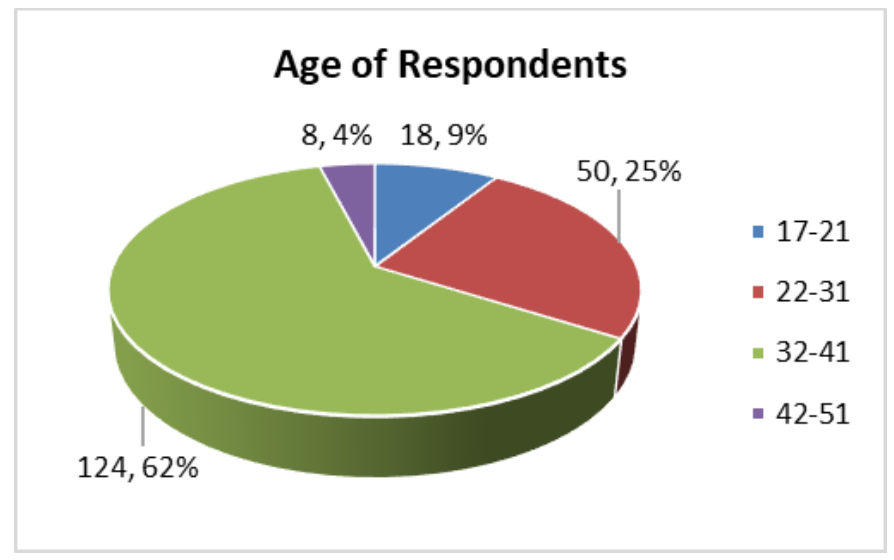

Figure 1. Age of Respondent

Data on the age of the respondents are in line with the results of the survey research from Wearesocial (Orenzi, 2019). Internet users in Indonesia are mostly in the age range of 14-34 years, which is 192 respondents. Meanwhile internet users in Indonesia today (in 2019) have reached 150 million. The time of internet access per day of the Indonesian population is 8 hours 36 minutes. They randomly do three hours to surf on social media, two hours are used to watch videos (YouTube), one hour are used to listen to streaming music. The rest can be of interest to business and access to other information (news, education, etc.). This shows that the use of the internet by the Indonesian population is only a small proportion who use it to access information or study.

\section{Overview of Student Learning Achievement in UT Mataram}

Student Learning Achievement or the Grade Point Average (GPA) of new students in the ECET program in 2020 at UT Mataram is illustrated in table 2. The table shows that the respondent's GPA is predominantly in the range 3.01-3.50 obtained with $60 \%$ of respondents (119 students) in the good category. Furthermore the vulnerability of the grades $2.51-3.00$ was achieved by 30\% (60 students). Thus the learning achievement of respondents in UT Mataram on average included in the good category. 
Table 2. Overview of student learning achievement

\begin{tabular}{lccc}
\hline Category & Score & Frequency & Percentage \\
\hline Very good & $3.51-4.00$ & 11 & 5 \\
Well & $3.01-3.50$ & 119 & 60 \\
Enough & $2.51-3.00$ & 60 & 30 \\
Low & $2.01-2.50$ & 6 & 3 \\
Very low & $<2.00$ & 4 & 2 \\
\hline \multicolumn{2}{c}{ Total Respondents } & 200 & \\
\hline
\end{tabular}

\section{Overview of Student's I-Literacy Skills}

Data on the I-literacy skills of new students of ECET Program at UT Mataram are presented in table 3 . The data in table 3 shows that the respondent's I-literacy skills are in the good category, because almost half of the students have a score with a good category of $49 \%$ or 98 students, while in the quite good category as many as $30 \%$ or as many as 60 students. These results show that new students of the ECET study program have good I-literacy skills or on average students can use the internet.

Table 3. Overview of student I-literacy skills

\begin{tabular}{cccc}
\hline Category & Score & Frequency & Percentage \\
\hline Very good & $20-24$ & 25 & 13 \\
Well & $15-19$ & 98 & 49 \\
Enough & $10-14$ & 60 & 30 \\
Low & $5-9$ & 14 & 7 \\
Very low & $0-4$ & 3 & 1 \\
\hline \multicolumn{2}{l}{ Total Respondent } & 200 & \\
\hline
\end{tabular}

The results of data analysis about correlations between student's I-literacy skills and student learning achievement at UT Mataram is presented in table 4 . The table shows the value of correlation coefficient or strength value of the correlation of 0.109 , meaning the level of relationship strength (correlation) between the utilization of student's I-literacy skills and Student Learning Outcomes that are equal to 0.109 or very weak, while the significance value or significance. (2-tailed) of $0.128>$ greater than 0.05 , which means that the correlation is not correlated, meaning that there is no significant relationship between the variable utilization of studen's I-literacy skills and Student Learning Achievement.

Table 4. Results of correlation analysis between student's I-literacy skills and Student Learning Achievement

\begin{tabular}{llrr}
\hline \multicolumn{2}{c}{ Correlations } & I-Literacy & GPA \\
\hline I-Literacy & Pearson Correlation & 1 & .109 \\
& Sig. (2-tailed) & & .128 \\
& Sum of Squares and & 2674.020 & 33.928 \\
& Cross-products & 13.643 & .173 \\
& Covariance & 200 & 200 \\
\hline GPA of & P & .109 & 1 \\
Respondent & Sig. (2-tailed) & .128 & 36.593 \\
& Sum of Squares and & 33.928 & .184 \\
& Cross-products & .173 & 200 \\
\hline
\end{tabular}


The results of this study are in line with the research conducted by ( $\mathrm{S}$. Tatminingsih and T.Prastati, 2011) which states that there is no correlation between students' ability to use the internet and their activity in accessing university websites with Student Learning Achievement. Despite the increase in the ability to use the internet. Similar results were also conveyed ( (O.C. Brudvik \& J. Hedberg, 2010) and (R. Weganofa and R. Lutviana, 2018)) stated that I-Lliteracy skills had no relation to the Student Learning Achievement.

The discussion of these results, described as frivolous. The results of this study indicate that Student Learning Achievement in distance education have nothing to do with ILiteracy skills. Although in distance higher education, students are required to have ILiteracy skills in the learning process, but these skills do not make students get high scores on their learning outcomes. This is very possible because the learning achievement of ODE students, especially Universitas Terbuka, are a combination of the value of the final semester exam and the scores of the tutorial. The final semester exam score is largely determined by the student's authority on the main material book or the course module. Independent learning in many ways is determined by the ability to learn effectively. The ability to learn depends on the speed of reading and the ability to understand the content of the reading (Lamusu, 2021). To be able to study independently, effectively, UT students are required to have self-discipline, initiative, and strong learning motivation. In addition, students in distance education are required to be able to study independently. The effectiveness of independent learning is determined by the ability to manage time, reading speed and the ability to understand the content of the reading. To be able to study independently effectively, UT students are required to have self-discipline, initiative, and strong learning motivation. Students are also required to be able to manage their time efficiently, so they can study regularly based on a self-determined study schedule (Terbuka, Katalog Sistem Penyelenggaraan Universitas Terbuka 2021/2022, 2021).

\section{Overview of domicile of students}

Data domicile measured using scores from the Likert scale are presented in table 5.

Table 5. Overview of domicile of students

\begin{tabular}{ccc}
\hline Skor of domicile & Frequency & Percentage \\
\hline $68-80$ & 98 & 49 \\
$56-67$ & 40 & 20 \\
$44-55$ & 31 & 16 \\
$32-43$ & 9 & 4 \\
$20-31$ & 11 & 11 \\
\hline Total Responden & 200 & \\
\hline
\end{tabular}

The results of data processing on student domicile are presented in table 5 . The data shows that 169 respondents scored 44-80, meaning that most of the respondents lived not too far from the final exam location, study group location and the Mataram UT office. In addition, their residence also has a fairly fast internet network and has good lighting or learning facilities. The data also shows that only a small number of new ECET students at UT Mataram live far away and have an internet network and inadequate lighting. This is because UT has anticipated the distance from where students live by holding an final exams and conducting tutorials in locations closest to the students' domicile. Meanwhile, regarding the internet network, UT collaborates with one of the internet service providers, namely Telkomsel to provide free internet access if students use an ecampus.ut.ac.id account with the username of the Student Identification Number.

\section{Correlation between domicile and Student Learning Achievement}


The results of data analysis about the relationship between student's domicile with Student Learning Achievement are presented in table 6. The value of correlation coefficient or strength value of relationships shown in table 5 is -0.165 , meaning the level of relationship strength (correlation) Among domicile relationships and Student Learning Achievement is positive, but very weak, while the significance value or significantly (2-tailed) of 0.02 smaller than 0.05 , which means correlated correlations. This stated meaning that there is a significant (meaningful) relationship between domicile and Student Learning Achievement. To be clearer, the results of the analysis are illustrated in table 6 .

Table. 6. Results of correlation analysis between domicile, and Student Learning Achievement

\begin{tabular}{|c|c|c|c|}
\hline \multicolumn{4}{|c|}{ Correlations } \\
\hline & & $\begin{array}{c}\text { Distance of } \\
\text { Domicile }\end{array}$ & GPA \\
\hline \multirow{5}{*}{$\begin{array}{l}\text { Distance of } \\
\text { Domicile }\end{array}$} & Pearson Correlation & 1 & $-.165^{*}$ \\
\hline & Sig. (2-tailed) & & .020 \\
\hline & $\begin{array}{l}\text { Sum of Squares and Cross- } \\
\text { products }\end{array}$ & 73291.885 & -270.105 \\
\hline & Covariance & 368.301 & -1.357 \\
\hline & $\mathrm{N}$ & 200 & 200 \\
\hline \multirow[t]{5}{*}{ GPA } & Pearson Correlation & $-.165^{*}$ & 1 \\
\hline & Sig. (2-tailed) & .020 & \\
\hline & $\begin{array}{l}\text { Sum of Squares and Cross- } \\
\text { products }\end{array}$ & -270.105 & 36.593 \\
\hline & Covariance & -1.357 & .184 \\
\hline & $\mathrm{N}$ & 200 & 200 \\
\hline
\end{tabular}

The results of the study are in line with Ratna Indriyani in Madura, Indonesia who stated that the results of the multivariate analysis she performed showed the influence between residence and learning achievement (Indriyani, 2014). The same opinion was conveyed by Bahtiar Afwan, who stated that students living in campus dormitories had better learning outcomes than those who lived in parents' homes (Bahtiar Afwan, 2017). Unlike Karnina and Fleury, which states that there is no relationship between residence and student learning achievement (Karnina, 2019) (Fleury, 2019).

The discussion of the results of this study is that Student Learning Achievement in Open Distance Education (ODE) or Open Distance Learning (ODL) have to do with student domicile even though the relationship is very weak. The closeness of the distance between the place of residence and the location of learning can affect learning achievement, because perhaps with the close distance of the level of student fatigue when heading to the location of learning can affect motivation and concentration. Nonetheless, these two factors need to be investigated further.

\section{CONCLUSION}

New student learning achievement in higher education that apply distance learning systems have nothing to do with domicile and I-literacy because learning achievement are determined by students' ability to study teaching materials, both printed and non-printed. Therefore, new students at a distance education should be equipped with the ability to read basic materials books and master study materials effectively and efficiently.

\section{ACKNOWLEDGMENTS}

I would like to thank University Terbuka especially the Dean of the Teaching and Education Faculty who has provided support and to students who have agreed to be respondents in this study. 


\section{REFERENCES}

A. Pramana, R.Watrianthos and I. Purnama. (2019). Sistem informasi pendaftaran Mahasiswa baru berbasis android. JJurnal Informatika UPGRIS Vol. 5, No. 2. P/E-ISSN: 24604801/2447-6645, 121-125. https:// doi.org/10.26877/jiu.v5i2.3807

Airin T and Clement EP. (2021). Gangguan Psikologis dan Kesejahteraan Psikologis pada Mahasiswa Baru. Psikologika: Jurnal Volume 26 Nomor 1. https://doi.org/10.20885/psikologika.vol26.iss1.art3

Bahtiar Afwan. (2017). Perbandingan Hasil Belajar Antara Siswa yang Tinggal di Asrama dengan Siswa yang Tinggal di Rumah Orang Tua pada Mata Pelajaran Sejarah Kelas X SMA Al-Kautsar Bandarlampung T.A 2015/2016. . Bandar Lampung: FKIP- Unila.

Brady, J. (2020). Introduction Visions of New Student Activism. Radical Teacher Lybrary. Vol 18. https:// doi.org/10.5195/rt.2020.868

Clement EP., et al. (2019). Gangguan Mental Emosional dan Kesepian pada Mahasiswa Baru. Mediapsi Volume 5 No 2. https://doi.org/10.21776/ub.mps.2019.005.02.4

Febrialismanto. (2021). Perbedaan Kemampuan Guru Menggunakan TIK Untuk Pengembangan Anak Usia Dini. Jurnal Obsesi: Jurnal Pendidikan Anak Usia Dini. Volume 5 Issue 2. https:// doi.org/10.31004/obsesi.v5i2.743

Fleury, A. (2019). Habilitation à Diriger des Recherches-Spécialité : Génie informatique et traitement du signal. Toulouse: InstitutMines-Télécom.

Haluti F., Layoo N. (2020). Profil Persepsi dan Motivasi Mahasiswa Baru Universitas Muhammadiyah Luwuk. Jurnal Pendidikan Glasser Volume 4 No 1. https://doi.org/10.32529/glasser.v4i1.451

Iflah and Winda Dwi L. (2013). Gambaran penyesuaian diri Mahasiswa baru . Jurnal Penelitian dan Pendidikan Psikologi Volume 2 No 2. https://doi.org/10.21009/JPPP.021.05

Indriyani, R. (2014). Pengaruh Asal Sekolah Dan Tempat Tinggal Terhadap Prestasi Belajar Mahasiswa Prodi D III Kebidanan Universitas Wiraraja Sumenep. (TESIS) . Surakarta: Universitas Sebelas Maret (UNS) Program Pascasarjana. .

Ines Rinera and, Sofia Retnowati. (2020). Pengaruh Pelatihan MBSR terhadap Kecemasan pada Mahasiswa Baru. Gadjah Mada Journal of Proffesional Psychology Volume 6 No 2. https:// doi.org/10.22146/gamajpp.56658

Karnina, R. (2019). The Comparison Of The Cumulative Grade Point Average On Medical Students Living In Dormitory And Boarding House Of A Medical School. Jurnal Pendidikan Kedokteran Indonesia - The Indonesian Journal of Medical Education Vol 8 No. 1, 17-24. https:// doi.org/10.22146/jpki.35778

Lamusu. (2021). Meningkatkan Kemampuan Menulis Mahasiswa Program Studi PG-PAUD melalui Pendekatan Saintifik. Jurnal Obsesi : Jurnal Pendidikan Anak Usia Dini Volume 5 No 1. https://doi.org/10.31004/obsesi.v5i1.609

Masani, Happy F., Alfroki M. (2021). New Student Admission Management Based Online. Advances in Social Science, Education and Humanities Research, volume 565. , 12451247. https:// doi.org/10.2991/assehr.k.210716.247

Nina A. Sokolova, et. al. (2018). The Pros And Cons of Distance Learning. Professional Culture of the Specialist of the Future 18th PCSF 2018 (pp. 1478-1486). United Kingdom: $\quad$ Future Academy www.FutureAcademy.org. https://doi.org/10.15405/epsbs.2018.12.02.157

Nurdin and Anhusadar . (2021). Efektivitas Pembelajaran Online Pendidik PAUD di Tengah Pandemi Covid 19. Jurnal Obsesi : Jurnal Pendidikan Anak Usia Dini. Volume 5 Issue 1. https:// doi.org/10.31004/obsesi.v5i1.699

O.C. Brudvik \& J. Hedberg. (2010). Scaffolding Learning Tasks to Achieve Internet literacy. ICDLL Conferences (pp. 1-10). Toronto: TU. 
Orenzi, B. (2019). Statistik Pengguna Digital Dan Internet Indonesia 2019 . New York: Wearesocial: $\quad$ https://www.boc.web.id/statistik-pengguna-digital-dan-internetindonesia-2019

R. Weganofa and R. Lutviana. (2018). The Correlation between internet Literacy and Passive . Lingua Cultural, 339-343. https:// doi.org/10.21512/lc.v12i4.4113

Rinera, I., Retnowati, S. (2020). Pengaruh Pelatihan MBSR terhadap Kecemasan pada. Gadjah Mada Journal of Professional Psychology Vol 6 No 2. https:// doi.org/10.22146/gamajpp.56658

S. Tatminingsih and T.Prastati. (2011). Peningkatan Kegiatan Belajar Mahasiswa Melalui Pemanfaatan Fasilitas Latihan Mandiri dalam Web site Universitas Terbuka (Laporan Penelitian). . Jakarta: Universitas terbuka.

Sinha, M. K. (2012). Status of ICT and Internet Literacy for Accessing to E-Resources Available underUGC-INFONET Digital Library Consortium : A Case Study. 8th Convention PLANNER-2012 (pp. 297-318). Ahmedabad: Sikkim University, Gangtok, March 01-03, 2012.

Suwena, K. (2017). Jalur Penerimaan Mahasiswa Baru Bukan Penentu. Ekuitas - Jurnal $\begin{array}{llllll}\text { Pendidikan } & \text { Ekonomi } & \text { Volume } & 5 & \text { No } & 2,\end{array}$ https:// doi.org/10.23887/ekuitas.v5i2.12749

Tatminingsih, S. (2021). Teaching Practice Patterns in ECE Teacher Program in Distance Education in Indonesia. Jurnal Obsesi : Jurnal Pendidikan Anak Usia Dini. Volume 5 Issue 1. https://doi.org/10.31004/obsesi.v5i1.599

Terbuka, U. (2021). Katalog Sistem Penyelenggaraan Universitas Terbuka 2021/2022. Jakarta: Universitas Terbuka.

Wahyu H., Aryono A., Aji P. (2016). Usability Laman Penerimaan Mahasiswa Baru UNNES. Scientific Journal of Informatics Vol 3 No 1. https://doi.org/10.15294/sji.v3i1.4611 